\title{
Investigation on physical activation of some Mongolian coals
}

\author{
Batkhishig Damdin ${ }^{1 *}$, Barnasan Purevsuren ${ }^{1}$, Yuanli Zhang ${ }^{2}$, Haizhen Sun², \\ Ariunaa Alyeksandr ${ }^{1}$, Ankhtuya Ariunbold ${ }^{1}$, Battsetseg Munkhtaivan ${ }^{1}$, \\ Namkhainorov Jargalsaikhan", Batbileg Sanjaa ${ }^{1}$ \\ ${ }^{1}$ Institute of Chemistry and Chemical Technology, Mongolian Academy of Sciences, \\ 4th Building of MAS, Ulaanbaatar, 13330, Mongolia \\ 2 State Key Laboratory of Coal Conversion, Institute of Coal Chemistry, Chinese Academy of Sciences, \\ Taiyuan, Shanxi, 030001 P.R.China
}

* Corresponding author: Batkhishigee@gmail.com; ORCID ID:0000-0003-2425-2846

Received: 3 October 2019; revised: 25 October; accepted: 15 November 2019

\begin{abstract}
Activation characteristics of four different Mongolian coals were investigated. The coals were carbonized at temperatures of $550{ }^{\circ} \mathrm{C}$ and the obtained samples were activated by preheated steam. The pore size, pore volume and surface areas of all activated carbons (AC) have been determined by adsorption of nitrogen $\left(\mathrm{N}_{2}\right)$ gas. The BET surface areas of Aduunchuluun (ACAC), Shivee Ovoo (SCAC), Baganuur (BCAC) coal and Ulaan Ovoo coals (UCAC) are 283, 205,251 and $460 \mathrm{~m}^{2} / \mathrm{g}$ respectively. Langmuir surface area is $283 \mathrm{~m}^{2} / \mathrm{g}$ of ACAC, $230 \mathrm{~m}^{2} / \mathrm{g}$ of SCAC, $537 \mathrm{~m}^{2} / \mathrm{g}$ in UCAC and $254 \mathrm{~m}^{2} / \mathrm{g}$ in BCAC.
\end{abstract}

Keywords: Carbonization, activation, surface area, micropores, mesopores

\section{INTRODUCTION}

Coals of varying quality are considered to be an abundant source for the manufacturing of activated carbons (AC). The activated carbons are often used as the adsorbents for removing impurities from drinking water, industrial outlet gases. Furthermore, ACs are basic materials of catalysts in the chemical industry, different kinds of coals are more frequently used as carbon resources for ACs. ACs are used as filtering and adsorbent materials for cleaning of toxic gas, drinking water, industrial wastewater and so on. Furthermore, ACs are bases of catalyst in the chemical industry, medicines in healthcare and special absorbent for cleaning the human blood [1]. Indeed, many conventional methods have been used for wastewater treatment such as precipitation, oxidation, flotationcoagulation, and electrocoagulation. Even they appear effective, they are limited to a variety of pollutant for technical reasons and a high cost of exploitation or may not be capable of treating large volumes of effluent [2]. Among the above mentioned methods for wastewater treatments that has drawn attention to many researchers in the last decades, adsorption using AC, a phase transfer process has been widely used in practice to remove contaminants in all their forms (organic and inorganic) from fluid phases because of the low investment in initial cost and design simplicity [3]. Therefore, the study of ACs characteristics obtained from coal is of viable importance nowadays. We have investigated above mentioned 4 coals from different deposits in Mongolia by physical activation method. Before activation, each coal sample was carbonized by pyrolysis at $550-650{ }^{\circ} \mathrm{C}$ for $120 \mathrm{~min}$ for the porous characteristics such as BET and Langmuir surface area, pore volume and pore size in ACs obtained from the coals.

\section{EXPERIMENTAL}

The ultimate and proximate analyses of coals used for the present study are shown in Table 1 . The coals were pulverized, ground and sieved, and the samples with particle sizes between $1.5-3 \mathrm{~mm}$ were selected the carbonization experiment. Approximately 400 grams of samples were loaded into the SNOL reactor and closed tightly to prevent any leakage. The reactor was switched on and the temperature was increased with the heating rate of $20^{\circ} \mathrm{C} / \mathrm{min}$ up to $550-600^{\circ} \mathrm{C}$. At this final temperature, the carbonization was continued for 120 minutes. The volatile products released during the carbonization process cooled down and liquid products 
were separated from the gaseous components by condensation. The yields of gaseous, liquid and solid products were determined by the weight difference. The solid residue called as a semi-coke obtained from the thermal decomposition of coal has been used as a sample for the preparation of activated carbon.

The semi-coke was sieved and the fractions with the particle size of $0.63-1.5 \mathrm{~mm}$ have been selected as an experimental sample. The 15 grams of the samples were loaded into a horizontal reactor and closed without any leakage. Afterward, the temperature was raised up to $800{ }^{\circ} \mathrm{C}$ with a heating rate of $5{ }^{\circ} \mathrm{C} / \mathrm{min}$. When the temperature inside the reactor was stabilized the saturated steam with the flow rate of $160 \mathrm{~cm}^{3} / \mathrm{min}$ was introduced into the reactor for 90 minutes.

The methodology for the determination of surface area, pore volume, pore size: The surface area of the activated carbon was determined by the adsorption of nitrogen with the flow rate of $3 \mathrm{~cm}^{3} / \mathrm{min}$ at STP. The surface area of the sample $\left(\mathrm{Sg}_{\mathrm{x}}\right)$ is calculated using the following equation:

$$
\operatorname{Sg}_{\mathrm{x}}=\frac{A_{x} \times W_{o}}{A_{o} \times W_{x}} \times \mathrm{Sg}_{0}
$$

Where, $A_{0}$ and $A_{x}$ are desorption area of the standard sample and the experimental sample, $W_{0}$ and $W_{x}$ sample and represent the weight of standard sample and experimental sample, $\mathrm{Sg}_{0}$ is surface area of the standard sample [4, 5].
The method of determining porous structure of AC by SEM analysis: The porous structure of ACs was observed by SEM. The SEM is made in Nikkiso Company of Japan, SEMTRAC mini SM-3000 mark, in high vacuum condition, with second electron detector, raiser up to $20-30.00 \mathrm{~V}$, and voltage $20 \mathrm{kV}$. Prepared samples were covered by gold metal after putting in the sample plat. The covered time is $60 \mathrm{sec}$ and the gold tin is $5-10 \mathrm{~nm}[6]$.

\section{RESULTS AND DISCUSSION}

The results of the proximate and ultimate analysis of initial coal samples from Shivee Ovoo, Ulaan Ovoo, Aduunchuluun, and Baganuur deposits are shown in Table 1. The brown coal is considered to be a relatively cheap raw material for preparation of AC. Nevertheless, some studies indicated that some coals contain more ash and sulfur and are not suitable for activation. For our selected coals, the ash content of Shivee Ovoo coal is higher $(21.17 \%)$ compared to the other three coals (Table 1). According to the proximate and ultimate analysis, the coals we studied showed close results to each other. The sample was pyrolyzed to the temperature of $550-600{ }^{\circ} \mathrm{C}$ with a heating rate of 20 ${ }^{\circ} \mathrm{C} /$ min for 120 minutes and the result shown in Table 2. Table 2 shows the solid residues (semi-coke) yield of pyrolysis $52-59 \%$ and the yields of thermal decompositions were generally approximate because the coals were with similar properties (Table1).

Table 1. The results of proximate and ultimate analyses of coals

\begin{tabular}{|c|c|c|c|c|}
\hline Deposit location & Shivee Ovoo & Ulaan Ovoo & Baganuur & Aduunchuluun \\
\hline Coal type & Lignite & Subbituminous coal & Lignite & Lignite \\
\hline \multicolumn{5}{|l|}{ Proximate analysis, $\%$} \\
\hline Moisture, Wa & 13.41 & 5.10 & 9.40 & 20.16 \\
\hline Volatile matter, Vdaf* & 42.57 & 46.8 & 47.0 & 48.0 \\
\hline Ash, $A^{d}$ & 21.17 & 4.90 & 13.30 & 13.50 \\
\hline Caloric value, $\mathrm{Q}^{\text {daf }}, \mathrm{kcal} / \mathrm{kg}$ & 6501 & 6218 & 5257 & 6363 \\
\hline \multicolumn{5}{|l|}{ Ultimate analysis, \% } \\
\hline Carbon, $C^{\text {daf }}$ & 71.36 & 74.6 & 70.5 & 66.75 \\
\hline Hydrogen, $\mathrm{H}^{\text {daf }}$ & 4.99 & 4.6 & 5.7 & 4.93 \\
\hline Nitrogen and oxygen, $(\mathrm{N}+\mathrm{O})^{\mathrm{daf}}$ & 22.59 & 31.40 & 41.50 & 26.10 \\
\hline Sulfur, St & 1.06 & 0.54 & 0.51 & 2.22 \\
\hline
\end{tabular}

${ }^{*}$ daf - dry ash free

Table 2. The yields of pyrolysis products at $550-650^{\circ} \mathrm{C}$

\begin{tabular}{llll}
\hline Samples & $\begin{array}{l}\text { Solid } \\
\text { residues, \% }\end{array}$ & $\begin{array}{l}\text { Liquid } \\
\text { products, \% }\end{array}$ & $\begin{array}{l}\text { Gas and } \\
\text { loss, \% }\end{array}$ \\
\hline Shivee Ovoo & 59.0 & 22.4 & 18.6 \\
\hline Aduunchuluun & 52.3 & 25.2 & 22.4 \\
Baganuur & 59.3 & 36.5 & 4.15 \\
Ulaan Ovoo & 58.3 & 22.2 & 19.5 \\
\hline
\end{tabular}

Table 3. Main technical characteristics of the pyrolysis solid residue of coals

\begin{tabular}{lllll}
\hline Samples & $\begin{array}{l}\text { Moisture,\% } \\
\text { W }^{\text {a }}\end{array}$ & $\begin{array}{l}\text { Ash, \% } \\
\mathbf{A}^{\mathbf{d}}\end{array}$ & $\begin{array}{l}\text { Volatile } \\
\text { matters, } \\
\% \text { Vdaf }\end{array}$ & $\begin{array}{l}\text { Caloric } \\
\text { value, } \mathbf{Q}^{\text {daf }} \\
\text { Kcal/Kg }\end{array}$ \\
\hline Shivee Ovoo & 0.1 & 27.4 & 16.2 & 7337.9 \\
\hline Aduunchuluun & 0.1 & 21.0 & 8.1 & 7126.3 \\
Baganuur & 2.8 & 13.9 & 8.3 & 6802.0 \\
Ulaan Ovoo & 0.8 & 24.7 & 4.3 & 6910.0 \\
\hline
\end{tabular}


Table 4. The result of activation by preheated water steam, and yield of $\mathrm{AC}$, methylene blue and iodine absorption

\begin{tabular}{|c|c|c|c|c|c|}
\hline \multirow[b]{2}{*}{ Samples } & \multirow[b]{2}{*}{$\mathrm{T},{ }^{\circ} \mathrm{C}$} & \multirow{2}{*}{$\begin{array}{l}\text { Time } \\
\text { min }\end{array}$} & \multirow{2}{*}{$\begin{array}{l}\text { Yield } \\
\%\end{array}$} & \multicolumn{2}{|c|}{ Absorption, $\mathrm{mg} / \mathrm{g}$} \\
\hline & & & & lodine & $\begin{array}{l}\text { Methylene } \\
\text { blue }\end{array}$ \\
\hline Shivee Ovoo & 800 & 90 & 51.6 & 26.3 & 373.8 \\
\hline Aduunchuluun & 800 & 90 & 54.3 & 28.1 & 366.3 \\
\hline Baganuur & 800 & 90 & 50.3 & 25.8 & 372.5 \\
\hline Ulaan Ovoo & 800 & 90 & 82.5 & 48.5 & 247.4 \\
\hline
\end{tabular}

During carbonization, was formed a semi-coke that is one of the main products and used to prepare AC after activation. For this reason, we have determined the main technical characteristics of the solid residue in (Table 3). In Table 3, the volatile matter content decreased 10 times for Ulaan Ovoo coal and it might form a more porous structure than others. For this reason, the semi coke produced after pyrolysis was activated by preheated water steam at $800{ }^{\circ} \mathrm{C}$ for 90 $\mathrm{min}$. Before activation, semi-coke was sieved 0.63 $\mathrm{mm}$ pieces. The result of determined yield of $A C$, methylene blue, and iodine absorption are shown in Table 4. The iodine absorption presents micropores of $\mathrm{AC}$ and methylene blue absorption presents the size of mesopores. As shown in Table 4, the yield of activated coals is $50.3-51.6 \%$ in brown coals (Aduunchuluun, Shivee Ovoo, Baganuur) and $82.5 \%$ in sub-bituminous coal (Ulaan Ovoo). The iodine absorption had more (48.5\%) in AC of Ulaan Ovoo coal than other ACs. In general, the iodine absorption has $500-1200 \mathrm{mg} / \mathrm{g}$ in commercial AC [6]. From this point of view, our $A C$ has less microporous than commercial AC. The surface area pore volume, pore size of the activated carbon was determined by the adsorption nitrogen. The isotherm linear of four ACs has been shown in Figure1. This isotherm linear indicates how the volume of the nitrogen absorbed at constant temperature and relative pressure.

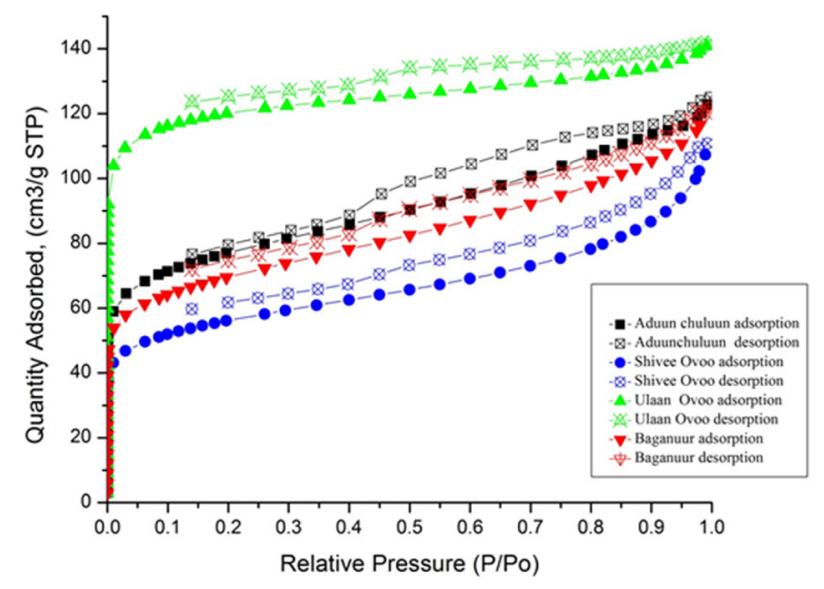

Fig. 1. Isotherm linear plot of ACs
From Figure 1, it can be obtained that the curve is complex and a combination of several physisorption isotherms types. In the part of low relative pressure, there is a large adsorption capacity, which is close to the adsorption isotherm of type I, and close to type II with the relative pressure increases, but the hysteresis Loops is type $\mathrm{H} 4$ according to the IUPAC classification, and type $\mathrm{H} 4$ loops are also often associated with narrow slit pores, type $\mathrm{H} 4$ are often found with micromesoporous carbons [4].

The AC of Ulaan Ovoo coal (maximum $130-140 \mathrm{~cm}^{3} / \mathrm{g}$ ) had more nitrogen absorption than others, and other deposits of activated carbons nitrogen absorption are approximate $100-120 \mathrm{~cm}^{3} / \mathrm{g}$. The estimate of activated carbon surface area is based on the BET method using nitrogen physical adsorption.

The Brunauer-Emmett-Teller method continues to be the most widely used procedure for evaluating the surface area of porous and finely-divided materials, in spite of the weakness of its theoretical foundations. Indeed, under certain carefully controlled conditions, the BET-area of a nonporous, macroporous or a mesoporous solid (i.e., giving a well-defined type II or a type IV(a) isotherm) can be regarded as the 'probe accessible area' (i.e., the effective area available for the adsorption of the specified adsorptive). According to the BET theory related to the multilayer adsorption, and Langmuir surface area related to the monolayer adsorption [7]. The results of determining the surface area of BET and Langmuir in the activated coals are shown in Table 5.

Table 5. BET and Langmuir surface area of AC

\begin{tabular}{lcccc}
\hline Samples & ACAC & SCAC & UCAC & BCAC \\
\hline $\begin{array}{l}\text { Langmuir surface } \\
\text { area, } \mathrm{m}^{2} / \mathrm{g}\end{array}$ & 283 & 205 & 460 & 251 \\
$\begin{array}{l}\text { BET surface area, } \\
\mathrm{m}^{2} / \mathrm{g}\end{array}$ & 283 & 230 & 537 & 254 \\
\hline
\end{tabular}

As shown in results, the BET surface area is $283 \mathrm{~m}^{2} / \mathrm{g}$ in ACAC, $205 \mathrm{~m}^{2} / \mathrm{g}$ in SCAC, $460 \mathrm{~m}^{2} / \mathrm{g}$ in UCAC and $251 \mathrm{~m}^{2} / \mathrm{g}$ in BCAC. And Langmuir surface area is 283 $\mathrm{m}^{2} / \mathrm{g}$ in ACAC, $230 \mathrm{~m}^{2} / \mathrm{g}$ in SCAC, $537 \mathrm{~m}^{2} / \mathrm{g}$ in UCAC and $254 \mathrm{~m}^{2} / \mathrm{g}$ BCAC. Generally, the BET surface area of trading activated carbon is $10-400 \mathrm{~m}^{2} / \mathrm{g}$ in the surface of mesoporous, whereas the micropores are $500-2000 \mathrm{~m}^{2} / \mathrm{g}$, while the surface area of our UCAC is near the standard of micropores while others are very small mesoporous predominates. One of the methods determining the pore size and pore volume is $\mathrm{BJH}$ analysis. $\mathrm{BJH}$ analysis can also be employed to determine pore area, average pore width (4 V/A) and specific pore volume using adsorption and desorption techniques. This technique characterizes pore size distribution independent of the external area due to the particle size of the sample [6, 7]. The result of BJH adsorption cumulative pore volume and $\mathrm{BJH}$ desorption 

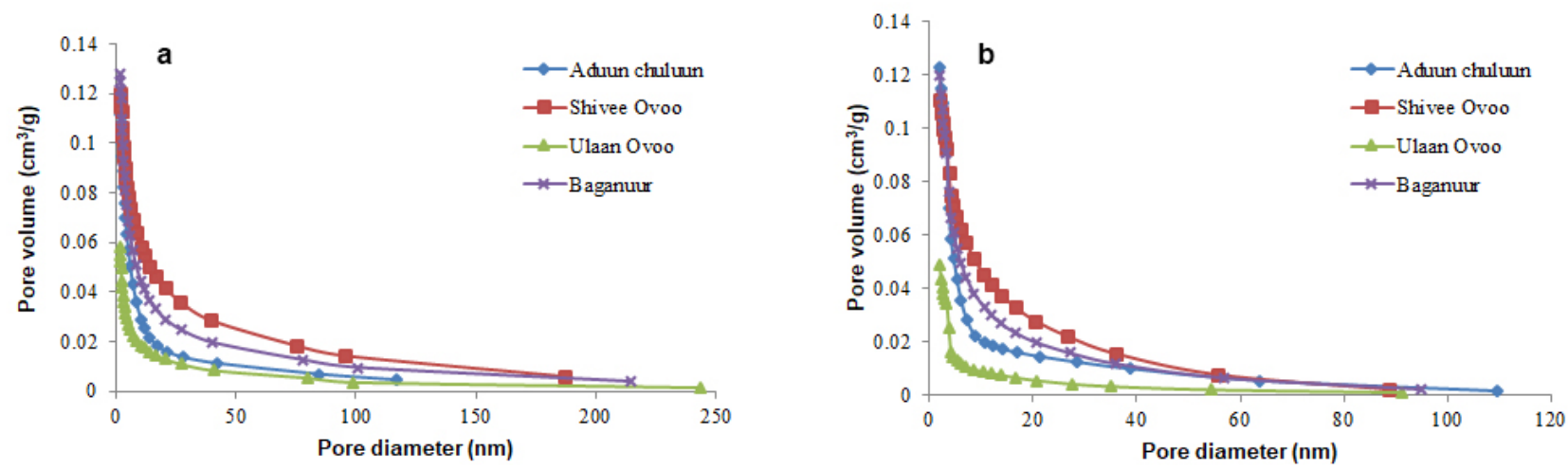

Fig. 2. The distribution curve of porous for activated carbons, $a$ - adsoption; $b$ - desorption

cumulative pore volume are presented in Figure 2.

BJH pore size distribution graph and data adsorption of ACs cumulative volume of pores between 1.7 and 300 $\mathrm{nm}$ diameter in BCAC $0.13 \mathrm{~cm}^{3} / \mathrm{g}$, ACAC $0.12 \mathrm{~cm}^{3} / \mathrm{g}$, SCAC $0.12 \mathrm{~cm}^{3} / \mathrm{g}$ and UCAC $0.06 \mathrm{~cm}^{3} / \mathrm{g}$, and BJH desorption of ACs cumulative volume of pores between 1.7 and $300 \mathrm{~nm}$ diameter in BCAC $0.12 \mathrm{~cm}^{3} / \mathrm{g}$, ACAC $0.12 \mathrm{~cm}^{3} / \mathrm{g}$, SCAC $0.11 \mathrm{~cm}^{3} / \mathrm{g}$ and UCAC $0.06 \mathrm{~cm}^{3} / \mathrm{g}$. The BJH adsorption pore volume is not greater than 0.7 $\mathrm{cm}^{3} / \mathrm{g}$. In addition, the pore volume and pore distribution of activated carbons are determined by the HorvathKawazoe method [5] and the result is shown in Table 6. As shown in Table 6, the adsorption average pore width (by the BET method) in SCAC $3.33 \mathrm{~nm}$, BCAC is 2.97 $\mathrm{nm}, A C A C$ is $2.72 \mathrm{~nm}$, and UCAC is $1.9 \mathrm{~nm}$. And the median pore width of SCAC is $0.48 \mathrm{~nm}, \mathrm{BCAC}$ is 0.48 $\mathrm{nm}, \mathrm{ACAC}$ is $0.47 \mathrm{~nm}$, and UCAC is $0.46 \mathrm{~nm}$ and there is more pore distribution with 0.4-0.6 nm.

The images of scanning electron microscopes (SEM) of activation carbons presented in Figure 3.
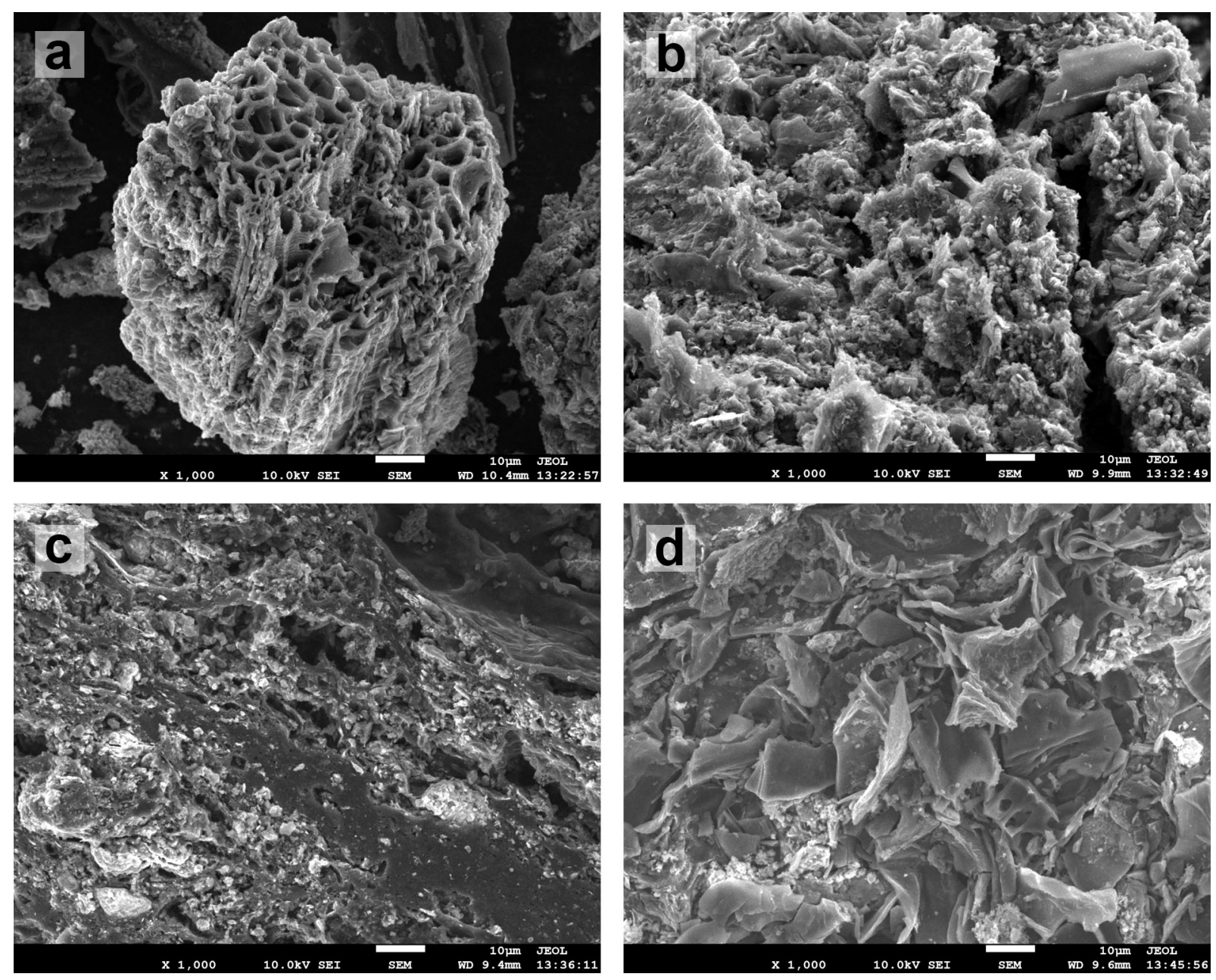

Fig. 3. SEM analysis of ACs, a - Aduunchuluun, b - Shivee Ovoo, c - Ulaan Ovoo, d - Baganuur 
Table 6. Horvath-Kawazoe cumulative volume and differential pore volume of $A C$

\begin{tabular}{lcc}
\hline Samples & Pore width, $\mathbf{n m}$ & Median pore width, $\mathbf{n m}$ \\
\hline SCAC & 3.33 & 0.48 \\
BCAC & 2.97 & 0.48 \\
ACAC & 2.72 & 0.47 \\
UCAC & 1.90 & 0.46 \\
\hline
\end{tabular}

The SEM analysis shows that pore structure is different for each coal and it can be observed in different sizes and shape pores. For example, in Figures $3 b, 3 c$, and $3 d$, the pore distribution is uneven and the hardness of the pores is not noticeable, which may indicate that the activation may be incomplete. The incomplete activation depends on coal characterization and processing to activation and which negatively affects the pore structure and the surface area. Figure $3 a$ has relatively large fluffy fibrous and there are macropores that are more obvious.

\section{CONCLUSION}

The activated carbon of Ulaan Ovoo coal had more nitrogen adsorption than others. In the case of Ulaan Ovoo coal of iodine absorption, BET surface area, and Langmuir surface area are close to the standard for the micro-surface area of activated carbon and the other coals have very fewer micropores.

\section{REFERENCE}

1. Chen X. (2015) Modeling of experimental adsorption isotherm data. Information, 6, 14-22. doi:10.3390/info6010014

2. Hamzaoui M., Bestani B and Benderdouche N. (2018) The use of linear and nonlinear methods for adsorption isotherm optimization of basic green 4-dye onto sawdust-based activated carbon. J. Mater. Environ. Sci., 2508(4), 1110-1118.

3. Purevsuren B., Lin C., Davaajav Y., Ariunaa A., Batbileg S., Avid B., Jargalmaa S., Huang $Y$ and Liou Y. (2015) Adsorption isotherms and kinetics of activated carbons produced from coals of different ranks. Water Sci. Technol., 71(8), 1189-1195. doi:10.2166/wst.2015.094

4. Thommes M., Kaneko K., Neimark A.V, Olivier J.P., Rodriguez-reinoso F., Rouquerol J and Sing K.S.W. (2015) Physisorption of gases, with special reference to the evaluation of surface area and pore size distribution ( IUPAC Technical Report). Pure Appllied Chem., 87, 1051-1069. doi:10.1515/ pac-2014-1117

5. Landers J., Gor Y.G and Neimark A.V. (2013) Density functional theory methods for characterization of porous materials. Colloids Surfaces A Physicochem. Eng. Asp., 3, 437. doi:10.1016/j.colsurfa.2013.01.007

6. Ariunaa A. (2011) Investigation of obtain activated carbons from coals by thermal processing. Ph.D thesis, University of Ulaanbaatar, Mongolia

7. Demirkıran N., Özdemir G.D.T., Saraç M., Dardağan M. (2017) Adsorption of methylene blue from aqueous solutions by pyrolusite ore. Mong. J. Chem., 18(44), 5-11. doi:10.5564/mjc.v18i44.880 